\title{
Design principles for transforming making programs into online settings at public libraries
}

\author{
Soo Hyeon Kim
}

Department of Library and Information Science, Indiana University Purdue University at Indianapolis, Indianapolis, Indiana, USA

$$
\text { Gi Woong Choi }
$$

Department of Computer Science, State University of New York at Oswego, Oswego, New York, USA, and

\author{
Yong Ju Jung \\ Department of Learning, Design, and Technology, \\ The Pennsylvania State University College of Education, University Park, \\ Pennsylvania, USA
}

\begin{abstract}
Purpose - This paper aims to investigate design principles for transforming existing making communities of practice within public libraries into online knowledge-building communities to support youths, families with young children and adult members' making and tinkering during COVID-19.

Design/methodology/approach - Building upon C4P and connected learning framework, the authors analyze existing literature and practitioner reports on informal learning projects related to making and STEM learning, family learning and online learning as well as emergent cases of innovative approaches in response to COVID-19 from public libraries, informal learning institutions and community groups.

Findings - The authors suggest 11 design principles around five areas: program design, facilitation, tools and materials, process documentation and sharing and feedback.

Originality/value - This work contributes to the information and learning sciences concerned with community engagement and knowledge creation by suggesting a design model to transform and sustain existing making communities of practice within public libraries into online knowledge-building communities during COVID-19.
\end{abstract}

Keywords Communities of Practice, Public libraries, Makerspace, Informal learning, Making, C4P, Connected learning

Paper type Conceptual paper

Public libraries continue to facilitate community engagement and knowledge creation during COVID-19; however, there is little evidence that their endeavors encompass transforming existing making programs into online settings (PLA, 2020). Given the extension of the society's contingency planning in remote work and online learning, libraries

This article is part of the special issue, "A Response to Emergency Transitions to Remote Online Education in K-12 and Higher Education," which contains shorter, rapid-turnaround invited works, not subject to double blind peer review. The issue was called, managed and produced on short timeline in Summer 2020 toward pragmatic instructional application in the Fall 2020 semester.

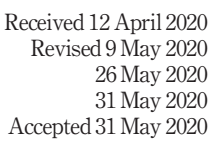

Accepted 31 May 2020

at public libraries 


\section{ILS}

$121,7 / 8$

\section{0}

will be expected to expand their online endeavors to continue their mission as knowledge creation institutions.

Public libraries have provided different types of making programs: STEAM programs (Koh et al., 2018); maker stations for digital fabrication and production (Moorefield-Lang, 2014); STEM kits (Rothstein, 2014); mobile makerspaces (Moorefield-Lang, 2015). While the maker movement - a community of people who make and share their products and processes in physical and/or virtual settings - plays a critical role toward knowledge creation (Koh and Abbas, 2016; Willett, 2015), hands-on and tool-dependent making programs are particularly challenging to translate into online settings. As such, public libraries during COVID-19 need support to transform existing making communities of practice $(\mathrm{CoP})$ into online settings.

To address this need, we provide evidence-based design principles for designing and facilitating online making programs for youths, families with young children, and adult members from existing making CoPs. Design principles refer to characteristics of a learning design process that can inform practice (van den Akker, 1999). We aim to serve US public libraries to: transform existing (face-to-face) $\mathrm{CoP}$ within their making programs into online knowledge-building communities; and strengthen the connected learning pathways even during quarantine. We review existing literature and emergent approaches to propose design principles around five areas (program design, facilitation, tools and materials, process documentation and sharing, feedback).

\section{C4P and connected learning framework}

We bring together the C4P framework (Hoadley and Kilner, 2005) and the connected learning framework (Ito et al., 2013) in our analysis. C4P stands for content, conversation, connections, (information) context, and purpose that facilitates learning within $\mathrm{CoP}$ in online learning environments. CoP, first coined by Lave and Wenger (1991), emphasizes that learning resides among practice and community (Hoadley, 2012; Looi et al., 2008). Hoadley and Kilner (2005) developed the C4P framework in accordance with a type of CoP, knowledge-building community; unlike other types of $\mathrm{CoP}$ where learning happens unintentionally, knowledge-building community members share a common goal of knowledge creation and learning. In $\mathrm{C} 4 \mathrm{P}$ framework, content refers to artifacts that function as vehicles of knowledge and initiate a unidirectional communication. Conversation means dialogues and discussions, which entail bidirectional interactions for information exchange. Connections involve members making interpersonal contacts thereby building a relationship. Context indicates information context that enables community members to evaluate the relevance of given information. Lastly, purpose provides the rationale for the establishment of the community. The five elements enable online community members to build knowledge effectively (Hoadley and Kilner, 2005).

We also adopt principles of connected learning framework (Ito and Martin, 2013) to building online making communities. Ito et al. (2009) identified three trajectories of participation in which modes of learning shift toward deepening interests and engagement: hanging out, messing around and geeking out (HOMAGO). Connected learning builds upon learning contexts that are peer supported, interest powered, academically oriented and promotes experiences that are purposeful, production centered and openly networked to enable HOMAGO opportunities (Ito et al., 2013). We incorporate the C4P framework and connected learning principles into online knowledge-building communities within library making programs. 
We reviewed existing literature and practitioner reports on informal learning projects that involve making and STEM learning, family learning and online learning. Given the practical nature of this paper, our analysis started with literature reviews of makerspaces from the public library (Willett, 2015) and educational research (Vossoughi and Bevan, 2014), and expanded our search to identify specific articles for youths, families and adults by leveraging our previous research (Choi and Pursel, 2016; Jung et al., 2016; Kim and Zimmerman, 2019). We searched for emergent cases in response to COVID-19 from existing and new community groups (CoBuild19, 2020; K-12 Remote Learning Resources, 2020; Programming Librarian Interest Group, 2014; Teaching During COVID-19, 2020) to survey how learning was supported during COVID-19 for community members. We attended to the types of learning activities that were implemented, and how community members shared their learning processes and outcomes. We reviewed a report on informal STEM learning (National Research Council, 2009) and online learning (Keengwe and Kidd, 2010) to identify facilitation techniques relevant to youths, families and adults in informal and/or online settings.

Adopting Herrington et al. (2009), we identified the substantive and procedural elements in existing making programs, particularly guided by C4P (Hoadley and Kilner, 2005) and the connected learning framework (Ito et al., 2013). Then, based on what we identified, we collaboratively established the design principles. Design principles around five areas emerged (program design, facilitation, tools and materials, process documentation and sharing, feedback).

\section{Design principles}

We present the 11 design principles to transform existing making CoPs at public libraries into online settings around five key areas (Table 1). We highlight that access to technology (e.g. computers) and the internet is a requirement to apply the proposed design principles because $\mathrm{CoP}$ members need them to engage in virtual-making programs. We also highlight that the design principles are intended to serve library staff who aim to transform their existing making programs into online maker communities. We also acknowledge that dropin programs for families with young children may have different characteristics than traditional CoPs; however, families who regularly attend these programs can transform into an online knowledge-building community with a shared goal during COVID-19. As such, each design principle provides additional guidelines for families with young children, if deemed appropriate.

\section{Program design}

Establish a shared, interest-driven purpose

"Clarity of purpose creates energy and produces results" (Hoadley and Kilner, 2005, p. 34). Establishing a shared purpose has been emphasized in makerspaces (Fontichiaro, 2016; Schön et al., 2014). Likewise, shared goals could motivate existing CoP members to continue their participation in online communities. Because involving youths in planning and designing programs can help their connected learning (Hoffman et al., 2016), library staff can use surveys and interviews to identify a shared purpose and check if the purpose is realistic based on the opportunities and limitations due to COVID-19. The shared purpose, then, should be clearly communicated in the online $\mathrm{CoP}$.

Shared purposes should be established based on $\mathrm{CoP}$ members' interests because learners engage in deeper learning when the subject closely tied to their personal interests (Brahms and Crowley, 2016; Calabrese Barton et al., 2016; Fields et al., 2015a; Kafai et al., 2014). To 


\section{ILS \\ $121,7 / 8$}

\begin{tabular}{|c|c|c|}
\hline Key areas & Design principles & Guidelines \\
\hline $\begin{array}{l}\text { Program } \\
\text { design }\end{array}$ & - Establish a shared, interest-driven purpose • & $\begin{array}{l}\text { - Use surveys, interviews, and/or teen } \\
\text { advisory board to incorporate CoP members' } \\
\text { interests and identify a shared purpose } \\
\text { Check if the purpose is realistic during } \\
\text { COVID-19 } \\
\text { Clearly communicate the purpose in the } \\
\text { online group }\end{array}$ \\
\hline
\end{tabular}

- Align activities with a collective social goal $\bullet$ Include making activities that relate to civic and political outcomes

- Combine individual and group-level activities at synchronous and asynchronous settings to support the desired learning practices

Tools and materials

- Provide instructions to engage in online platforms

- Use simple and low-tech materials

- Facilitate connections

- Facilitate the maker mindset

\section{Table 1.}

Design principles for Process • Use technology for documenting and transforming making documentation sharing programs into online and sharing settings at public libraries
- Consider how different structures (e.g. individual vs group-level) and formats (e.g. synchronous vs asynchronous) of activities support the learning practices within $\mathrm{CoP}$

- Combine different structures and formats appropriately to support the desired learning practices

- Provide instructions on tool usage for technologically novice $\mathrm{CoP}$ members using online platforms (e.g. Zoom)

- Understand affordances of different tools and technologies and create proper manuals for $\mathrm{CoP}$ members to use

- Use community groups (e.g., Library Think Tank, Programming Librarian Interest Group) to design accessible programs using everyday materials

Facilitation • Facilitate "hanging out" conversations first • Identify a designated online $\mathrm{CoP}$ facilitator

- Use social media (e.g. TikTok, Instagram, Snapchat, Slack) to promote "hanging out" conversations

- Showcase a variety of examples and highlight diverse types of artifacts that patrons created

- Amplify examples to spark new connections among different members

- Design special contests or challenges to meet others and receive feedback

- Spark engagement through modeling or parallel play

- Reframe mistakes as drafts (e.g., what if, could be, let's try it out)

Provide specific feedback and compliments on the process (e.g., I like the way you tried three different ways to solve the problem) Provide ample exploration and play time with tools before posing explicit design problems

- Facebook pages, YouTube videos, community group pages, and VoiceThread can be useful documentation and sharing tools 


\begin{tabular}{|c|c|c|c|}
\hline Key areas & Design principles & Guidelines & $\begin{array}{l}S \\
\mathrm{C}\end{array}$ \\
\hline \multirow[t]{2}{*}{ Feedback } & $\begin{array}{l}\text { - Provide responsive feedback through } \\
\text { inquiry cycles }\end{array}$ & $\begin{array}{l}\text { - Create a document that library staff use to } \\
\text { identify challenges that patrons encounter } \\
\text { and suggest appropriate strategies that have } \\
\text { worked well } \\
\text { - The document needs to be updated through } \\
\text { the inquiry cycle of observation, support and } \\
\text { reflection }\end{array}$ & libraries \\
\hline & - Build multiple layers of social support & $\begin{array}{l}\text { - Design activities to support receiving } \\
\text { feedback from small peer group, bigger } \\
\text { group and experts }\end{array}$ & \\
\hline
\end{tabular}

reflect youths' interests in the making programs, teen advisory board (Subramaniam et al., 2018) can be used. Surveys, interviews and frequent conversations can also be strategies to identify $\mathrm{CoP}$ members' interests. Library staff need to compare $\mathrm{CoP}$ members' interests and realistic conditions of their libraries. For example, if a library were to transform youth film club into an online setting, a starting point can be examining youths' interests that can be supported without the use of recording and editing equipment located in the library. Then, they can find the alignments between their interests and the purpose of CoP. For family online making programs, library staff should consider the type of family they intend to serve and an appropriate purpose for them. Library staff need to re-examine the family members who may struggle to shift learning from school and in-person to home and online due to COVID-19. Library staff also need to be cognizant in their communication to be sensitive toward idiosyncratic struggles across families and establish a shared purpose that speaks to family members' experiences.

\section{Align activities with a collective social goal}

Programs for online $\mathrm{CoP}$ can be designed for a bigger, collective social goal to trigger motivation (Vossoughi et al., 2013) and enhance the sense of community (Fields et al., 2015a). Calabrese Barton et al. (2016) found that youths critically engaged in the makerspaces when their projects were closely related to social issues and political outcomes (e.g. gender and race issues). Similarly, a sewing club as a CoP could aim to design masks for front line workers - as a social goal - by running virtual sewing sessions from libraries. Such activities can provide opportunities for $\mathrm{CoP}$ members to contribute toward the larger society and engage in scientific investigation and creative idea generation to identify suitable materials and efficient sewing methods.

\section{Combine individual and group-level activities at synchronous and asynchronous settings to support the desired learning practices}

There are different learning practices that can happen in makerspaces. Wardrip and Brahms (2015) report seven learning practices: inquire; tinker; seek and share resources; hack and repurpose; express intention (refinement of identity and interests); develop fluency; and simplify to complexify (combine components to make new meanings). To support these practices, we recommend library staff to consider various combinations of different structures (e.g. individual vs group-level) and formats (e.g. synchronous vs asynchronous) of activities. For instance, a youth Scratch coding club could run a weekly Zoom session (synchronous) for a group of $\mathrm{CoP}$ members to inquire and tinker so that they could 


\section{ILS}

$121,7 / 8$

624

collectively explore a coding procedure (e.g. using loops to standardize behavior). Then, a synchronous individual time could follow for each CoP member to create their own finished products and develop fluency. Furthermore, CoP members could asynchronously engage in hack and repurpose practices by modifying their previous products individually, and then seek and share resources with other $\mathrm{CoP}$ members as a group, which can support learners to discover new paths for inquiry.

The three design principles for program design provide guidelines to outline the objective and direction of online making programs. Then, we encourage library staff to use existing resources that provide ideas for curriculum and informal activities categorized by age, topic, content and subject areas (Exploratorium, 2020; Indiana State Library, 2020; Tinkering Studio, 2020).

\section{Tools and materials}

Provide instructions to engage in online platforms

Library staff need to provide adequate instructions on how to engage in making practices through online platforms, especially for patrons who may not be familiar with online tools. Library staff need to invest time to understand educational affordances of various online tools (e.g. Slack, Twitch, Google Hangouts) and provide step-by-step instructions for patrons to ensure a safe online learning space (Bakija, 2020). For instance, Zoom, a video communication tool, is offering free webinars for first-time users and resources about privacy and security while using Zoom (Zoom, 2020).

\section{Use simple and low-tech materials}

Providing materials in accessible way is critical for makerspaces (Brahms, 2014; Litts, 2015). Library staff need to revisit the definition of accessibility during COVID-19 for diverse patrons, and use simple and low-tech materials for virtual making programs. For instance, providing a virtual quilling program that uses everyday materials (e.g. paper toilet rolls, scissors, glue) allows patrons to participate without the need to purchase additional materials. Library staff can also use public Facebook groups (Library Think Tank, 2011; Programming Librarian Interest Group, 2014) to search for more accessible programs using everyday materials.

\section{Facilitation}

Facilitate "hanging out" conversations first

Connected learning framework highlights the importance of "hanging out" that can progressively shift toward other participation. As quality content, clear purpose, and personal connections are emphasized in conversation in online knowledge-building community (Hoadley and Kilner, 2005), to transform existing CoP to an online community, we highlight the importance of first facilitating $\mathrm{CoP}$ members' personal and casual conversations in the online community. Roque et al. (2016) illustrated that frequent and welcoming posts can support $\mathrm{CoP}$ members to get to know one another and engage in future activities. Keengwe and Kidd (2010) highlighted the importance of the online facilitator to provide cognitive, affective and managerial support. As such, libraries could have a designated online facilitator who use social media that are familiar to each patron group to pique their interests. For instance, creating new memes and hosting a social media challenge using various mediums (e.g. TikTok, Instagram, Snapchat, Slack) can be used to facilitate new conversations while youths "hang out". 
Connections foster relationships for $\mathrm{CoP}$ members to continue their participation toward the shared purpose. "Without connections, an online space is merely a document repository (content) or chat room (conversation)” (Hoadley and Kilner, 2005, p. 34). We suggest showcasing a variety of examples and highlighting diverse types of artifacts that patrons created (Sheridan et al., 2014; Vossoughi et al., 2013), and amplifying examples to spark new connections among different members (Roque et al., 2016). Connections could be facilitated through designing special contests and challenges to meet others and receive feedback (Fields et al., 2015a). CoBuild19 is a good example (Cox, 2020). CoBuild19, a Facebook group sharing different making activities developed by educators and researchers to facilitate STEM learning at home, is a hub where families showcase their artifacts, share ideas and ask questions about making at home.

For family groups, connections need to be first fostered within family members. An intergenerational experience provides opportunities for family members to learn together, collaborate and translate abstract concepts into personally-relevant knowledge that is anchored in real-world contexts (National Research Council, 2009). Also, equal participation and collaboration from family members can enhance children's learning (Gutwill and Allen, 2010; Yip et al., 2017). Thus, online making programs should invite caregivers to participate in making programs as co-learners.

\section{Facilitate the maker mindset}

The Maker Movement has drawn educators for the potential to facilitate the maker mindset in which learners embrace risks and failures to translate ideas into reality (Dougherty, 2013). Although developing the maker mindset requires long-term commitment, aiming toward this goal is still important to help learners find confidence and take a dispositional shift to view themselves as change agents. We synthesize a few guidelines based on literature to facilitate the maker mindset:

- $\quad$ initiate engagement through modeling or parallel play (Bevan et al., 2015);

- reframe mistakes as drafts by using phrases like "what if, could be, maybe, perhaps, let's try it out, etc." (Vossoughi et al., 2013, p. 4);

- provide specific feedback and compliments on the process by using phrases like "I like the way you tried three different ways to solve the problem." (Regalla, 2016); and

- provide ample exploration and play time with tools before posing explicit design problems (Kim and Zimmerman, 2017; Sheridan and Konopasky, 2016).

Also, library staff could redefine their role as a facilitator or mentor instead of traditional role of an expert (Clegg and Subramaniam, 2018). In this role, library staff could learn new skills and technologies with patrons, and attend to interaction patterns among them to suggest new ways that learners can contribute toward $\mathrm{CoP}$.

\section{Process documentation and sharing}

Use technology for documenting and sharing

Documenting and sharing the processes of making can support learners to reflect on their processes and receive constructive feedback (Sheridan et al., 2014). Peppler et al. (2019) illustrated that process documentation in makerspaces can provide ways to be recognized, as well as opportunities to engage in professional work practices and broader media production. Youth $\mathrm{CoP}$ members from their study use Facebook page, YouTube and community group page to document their design process to receive feedback from others. In 


\section{ILS}

$121,7 / 8$

\section{6}

an online graduate course on makerspaces, students use VoiceThread to share their iterative design processes along with pictures and videos of their final products (Oliver et al., 2017). VoiceThread supported multiple functionalities, such as integration with mobile devices to capture images while making, video sharing, drawing on slides and allowing the instructor to share modeling of process; these functionalities could make documenting and sharing easier. Library staff could use such technology to support documentation and sharing.

\section{Feedback}

Provide responsive feedback through inquiry cycles

Getting just-in-time, iterative feedback is an important aspect of a makerspace (Brahms and Crowley, 2016; Calabrese Barton et al., 2017). To provide effective feedback, we suggest adopting a responsive facilitation model that was developed to support each family's needs throughout the cycle of observation, support and reflection with a museum (Pattison $e$ al., 2017). Likewise, library staff can run remote, synchronous making sessions for small groups, observe the processes of their making, find where they struggle and provide responsive, real-time feedback in accordance with their situations. Library staff could also prepare a document that identifies challenges that patrons encountered and suggest appropriate strategies that have worked well, which should be frequently updated as they experience new situations.

\section{Build multiple layers of social support}

For online $\mathrm{CoP}$, providing multiple levels of social support for collaboration can be helpful to facilitate constructive criticism. Getting feedback from diverse perspectives (e.g. small peer group, bigger group with the whole class and experts) is critical to enhance the quality of learning and making projects (Bevan et al., 2015; Fields et al., 2015b; Roque et al., 2012). Public libraries could adopt a similar model to involve multiple layers of social support. For instance, if a synchronous remote maker session with families is implemented, library staff could let families share feedback with each other. Library staff could also use library website for learners to share their making projects and get feedback from one another. For feedback from experts, libraries could hold online making exhibitions and invite domain experts and community stakeholders so that learners can show their making projects and receive constructive feedback.

\section{Conclusion}

In this paper, we propose evidence-based design principles around the five areas - program design, facilitation, tools and materials, process documentation and sharing, and feedback for public libraries to build online, remote making programs during COVID-19. We integrate and apply theories related to the communities of practice and the connected learning to provide concrete guidelines and pathways throughout 11 design principles for different types of learner groups (i.e. youths, adults and families with young children) and diverse online making and tinkering activities.

The proposed design principles are still preliminary that warrant future studies to establish more specific practices and guidelines. We recognize that even with appropriate technology and Internet access, some may feel exhausted by online meetings and resources (e.g. Zoom fatigue), which could hinder their participation in online making efforts. Furthermore, online making programs may not fully support the serendipitous discovery and exploration that learners would experience in physical makerspaces. Our approach, however, is to support public libraries maintain making communities even during quarantine. Accordingly, our work can contribute to academic and practical discussions on 
temporary and potentially sustainable online making communities within public libraries in Online settings the field of information and learning sciences.

\section{References}

Bakija, M. (2020), "Libraries offer virtual meeting rooms on zoom", available at: www.libraryjournal. com/?detailStory=libraries-offer-virtual-meeting-rooms-on-zoom (accessed 7 May 2020).

Bevan, B., Gutwill, J.P., Petrich, M. and Wilkinson, K. (2015), "Learning through STEM-Rich tinkering: Findings from a jointly negotiated research project taken up in practice", Science Education, Vol. 99 No. 1, pp. $98-120$.

Brahms, L. (2014), Making as a Learning Process: Identifying and Supporting Family Learning in Informal Settings, University of Pittsburgh.

Brahms, L. and Crowley, K. (2016), "Learning to make in the museums: the role of maker educators", in Peppler, K., Halverson, E. and Kafai, Y. (Eds), Makeology: Makerspaces as Learning Environments, Vol. 1, Routledge, New York, NY, pp. 15-29.

Calabrese Barton, A., Tan, E. and Greenberg, D. (2017), "The makerspace movement: sites of possibilities for equitable opportunities to engage underrepresented youth in STEM", Teachers College Record, Vol. 119 No. 6, pp. 11-44.

Calabrese Barton, A., Tan, E. and Shin, M. (2016), "Mobilities of criticality: space-making, identity and agency in a youth-centered makerspace", Transforming Learning, Empowering Learners: The International Conference of the Learning Sciences (ICLS), International Society of the Learning Sciences, Singapore, pp. 290-297.

Choi, G.W. and Pursel, B.K. (2016), "Acceptance model of learning technologies in media commons", Transforming Learning, Empowering Learners: The International Conference of the Learning Sciences (ICLS) 2016, International Society of the Learning Sciences, Singapore, pp. 1243-1244.

Clegg, T. and Subramaniam, M. (2018), "Redefining mentorship in facilitating interest-driven learning in libraries", in Lee, V.R. and Philips, A.L. (Eds), Reconceptualizing Libraries: Perspectives from the Information and Learning Sciences, Routledge, pp. 140-157.

CoBuild19 (2020), available at: www.facebook.com/groups/CoBuild19/ (accessed 25 February 2020).

Cox, E. (2020), "Facebook group with activities for kids also used for research", The Herald Times, available at: www.hoosiertimes.com/herald_times_online/news/local/facebook-group-withactivities-for-kids-also-used-for-research/article_e7717338-95ec-11ea-9238-5f5708c2ec9a.html (accessed 19 May 2020).

Dougherty, D. (2013), “The maker mindset”, in Honey, M. and Kanter, D.E. (Eds), Design, Make, Play: Growing the Next Generation of STEM Innovators, Routledge, pp. 7-16.

Exploratorium (2020), "Exploratorium”, available at: www.exploratorium.edu/ (accessed 7 May 2020).

Fields, D., Pantic, K. and Kafai, Y.B. (2015a), "I have a tutorial for this': the language of online peer support in the scratch programming community", 4th International Conference on Interaction Design and Children, pp. 229-238.

Fields, D., Vasudevan, V. and Kafai, Y.B. (2015b), “The programmers' collective: fostering participatory culture by making music videos in a high school scratch coding workshop", Interactive Learning Environments, Vol. 23 No. 5, pp. 613-633.

Fontichiaro, K. (2016), "Sustaining a makerspace”, Teacher Librarian, Vol. 43 No. 3, pp. $39-41$.

Gutwill, J.P. and Allen, S. (2010), "Facilitating family group inquiry at science museum exhibits", Science Education, Vol. 94 No. 4, pp. 710-742.

Herrington, A., Herrington, J. and Mantei, J. (2009), "Design principles for mobile learning", in Herrington, J., Herrington, A., Mantei, J., Olney, I. and Ferry, B. (Eds), New Technologies, New Pedagogies: Mobile Learning in Higher Education, Faculty of Education, University of Wollongong, pp. 129-138. 


\section{ILS \\ $121,7 / 8$}

Hoadley, C. (2012), "What is a community of practice and how can we support it?", in Jonassen, D.H. and Land, S.M. (Eds), Theoretical Foundations of Learning Environments, 2nd ed., Rou, New York, NY, pp. 287-300.

Hoadley, C. and Kilner, P.G. (2005), "Using technology to transform communities of practice into Knowledge-Building communities", ACM SIGGroup Bulletin, Vol. 25 No. 1, pp. 31-40.

Hoffman, K.M., Subramaniam, M., Kawas, S., Scaff, L. and Davis, K. (2016), Connected Libraries: Surveying the Current Landscape and Charting a Path to the Future, College Park, MD; Seattle, WA.

Indiana State Library (2020), “Activities and resources for the COVID-19 crisis”, available at: https:/ continuinged.isl.in.gov/resource-page-covid-19-crisis/ (accessed 7 May 2020).

Ito, M. and Martin, C. (2013), "Connected learning and the future of libraries", Young Adult Library Services, Vol. 12 No. 1, pp. 29-32.

Ito, M., Baumer, S., Bittanti, M., Boyd, D., Cody, R., Herr-Stephenson, B., Horst, H.A., et al. (2009), "Hanging out", Messing around, and Geeking out: Kids Living and Learning with New Media, The MIT Press, Cambridge, MA.

Ito, M., Gutiérrez, K., Livingstone, S., Penuel, B., Rhodes, J., Salen, K., Schor, J., et al. (2013), Connected Learning: An Agenda for Research and Design, Digital Media and Learning Research Hub.

Jung, Y.J., Yan, S. and Borge, M. (2016), "Problems with different interests of learners in an informal CSCL setting", Proceedings of International Conference of the Learning Sciences, ICLS, Vol. 2, pp. 878-881.

K-12 Remote Learning Resources (2020), available at: https://app.slack.com/client/T0102T77LE4/ learning-slack (accessed 5 May 2020).

Kafai, Y.B., Fields, D.A. and Searle, K.A. (2014), "Electronic textiles as disruptive designs: Supporting and challenging maker activities in schools", Harvard Educational Review, Vol. 84 No. 4, pp. 532-556.

Keengwe, J. and Kidd, T. (2010), "Towards best practices in online learning and teaching in higher education”, MERLOT Journal of Online Learning and Teaching, Vol. 6 No. 2, pp. 533-541.

Kim, S.H. and Zimmerman, H.T. (2017), "Collaborative argumentation during a making and tinkering afterschool program with squishy circuits", Proceedings of the 12th International Conference on Computer Supported Collaborative Learning (CSCL), Philadelphia, PA, pp. 676-679.

Kim, S.H. and Zimmerman, H.T. (2019), "Understanding the practices and the products of creativity: Making and tinkering family program at informal learning environments", Proceedings of the 18th ACM International Conference on Interaction Design and Children, ACM, pp. 246-252.

Koh, K. and Abbas, J. (2016), "Competencies needed to provide teen library services of the future: a survey of professionals in learning labs and makerspaces", Journal of Research on Libraries and Young Adults, Vol. 7 No. 2, pp. 1-22.

Koh, K., Abbas, J. and Willett, R. (2018), "Makerspaces in libraries", in Lee, V.R. and Philips, A.L. (Eds), Reconceptualizing Libraries: Perspectives from the Information and Learning Sciences, Routledge, New York, NY, pp. 17-36.

Lave, J. and Wenger, E. (1991), Situated Learning: Legitimate Peripheral Participation, Cambridge University Press.

Library Think Tank (2011), available at: www.facebook.com/groups/ALAthinkTANK/ (accessed 25 February 2020).

Litts, B.K. (2015), "Resources, facilitation, and partnerships: three design considerations for youth makerspaces", Proceedings of the 14th International Conference on Interaction Design and Children, ACM, Medford, MA, pp. 347-350.

Looi, C.-K., Lim, W.-Y. and Chen, W. (2008), "Communities of practices for continuing professional development in the Twenty-First century", in Voogt, J. and Knezek, G. (Eds), International 
Handbook of Information Technology in Primary and Secondary Education, Springer, Online settings pp. 489-505.

Moorefield-Lang, H.M. (2014), "Makers in the library: case studies of 3D printers and maker spaces in library settings", Library Hi Tech, Vol. 32 No. 4, pp. 583-593.

Moorefield-Lang, H.M. (2015), "When makerspaces go mobile: case studies of transportable maker locations", Library Hi Tech, Vol. 33 No. 4, pp. 462-471.

National Research Council (2009), Learning Science In Informal Environments: People, Places, And Pursuits, in Bell, P., Lewenstein, B., Shouse, A. and Feder, M.A., (Eds), National Academies Press, Washington, DC, doi: 10.17226/12190.

Oliver, K.M., Moore, R.L., Evans, M.A. and Carolina, N. (2017), "Establishing a virtual makrespace for an online graduate course: a design case", International Journal of Designs for Learning, Vol. 8 No. 1, pp. 112-123.

Pattison, S.A., Randol, S.M., Benne, M., Rubin, A., Gontan, I., Andanen, E., Bromley, C., et al. (2017), "A design-based research study of staff-facilitated family learning at interactive math exhibits", Visitor Studies, Vol. 20 No. 2, pp. 138-164.

Peppler, K., Keune, A. and Peppler, K. (2019), "It helps create and enhance a community ': youth motivations for making portfolios making portfolios”, Mind, Culture, and Activity, Vol. 26 No. 3, pp. 234-248.

PLA (2020), "Public libraries respond to COVID-19", available at: www.ala.org/pla/issues/covid-19/ surveyoverview.

Programming Librarian Interest Group (2014), available at: www.facebook.com/groups/ ProgrammingLibrarianInterestGroup/ (accessed 25 May 2020).

Regalla, L. (2016), "Developing a maker mindset”, in Peppler, K., Halverson, E. and Kafai, Y.B. (Eds), Makeology: Makerspaces as Learning Environments, Vol. 1, Routledge, New York, NY, pp. 257-272.

Roque, R. Kafai, Y. and Fields, D. (2012), "From tools to communities: designs to support online", pp. 220-223.

Roque, R., Rusk, N. and Resnick, M. (2016), "Supporting diverse and creative collaboration in the scratch online community", in Cress, U., Moskaliuk, J. and Jeong, H. (Eds), Mass Collaboration and Education, Springer, Cham, Heidelberg, New York, NY, Dordrecht, London, pp. 241-256.

Rothstein, E. (2014), "Library offering 'STEM kits' for children”, available at: www.arlnow.com/2014/ 08/01/library-offering-stem-kits-for-children/ (accessed 7 May 2020).

Schön, S., Ebner, M. and Kumar, S. (2014), "The maker movement. Implications of new digital gadgets, fabrication tools and spaces for creative learning and teaching", ELearning Papers, Vol. 39, pp. 1-12.

Sheridan, K. and Konopasky, A. (2016), "Designing for resourcefulness", in Peppler, K., Halverson, E. and Kafai, Y.B. (Eds), Makeology: Makerspaces as Learning Environments, Vol. 1, Routledge, New York, NY and London.

Sheridan, K., Halverson, E.R., Litts, B., Brahms, L., Jacobs-Priebe, L. and Owens, T. (2014), "Comparative case study of three makerspaces", Harvard Educational Review, Vol. 84 No. 4, pp. 505-532.

Subramaniam, M., Scaff, L., Kawas, S., Hoffman, K.M. and Davis, K. (2018), "Using technology to support equity and inclusion in youth library programming: current practices and future opportunities", The Library Quarterly, Vol. 88 No. 4, pp. 315-331.

Teaching During COVID-19 (2020), available at: www.facebook.com/groups/259567351732867/about/ (accessed 5 May 2020).

Tinkering Studio (2020), “Tinkering studio”, available at: www.exploratorium.edu/tinkering (accessed 7 May 2020). 


\section{ILS}

$121,7 / 8$

630

van den Akker, J. (1999), "Principles and methods of development research", Design Approaches and Tools in Education and Training, Springer, Dordrecht, pp. 1-14.

Vossoughi, S. and Bevan, B. (2014), "Making and tinkering: a review of the literature", Commissioned Paper for Successful Out-of-School STEM Learning, Washington, DC., pp. 1-55.

Vossoughi, S., Escudé, M., Kong, F. and Hooper, P. (2013), “Tinkering, learning and equity in the afterschool setting", Proceedings of the Annual Conference on Creativity and Fabrication in Education, pp. 1-8.

Wardrip, P.S. and Brahms, L. (2015), "Learning practices of making: developing a framework for design", Proceedings of the 14th International Conference on Interaction Design and Children IDC '15, pp. 375-378.

Willett, R. (2015), "Making, makers, and makerspaces: a discourse analysis of professional journal articles and blog posts about makerspaces in public libraries", The Library Quarterly, Vol. 86 No. 3, pp. 313-329.

Yip, J.C., Sobel, K., Pitt, C., Lee, K.J., Chen, S., Nasu, K. and Pina, L.R. (2017), "Examining adult-child interactions in intergenerational participatory design", Conference on Human Factors in Computing Systems - Proceedings, Vol. 2017-May, pp. 5742-5754.

Zoom (2020), "Support during the COVID-19 pandemic", available at: https://zoom.us/docs/en-us/ covid19.html (accessed 7 May 2020).

\section{Corresponding author}

Soo Hyeon Kim can be contacted at: skim541@iu.edu

For instructions on how to order reprints of this article, please visit our website: www.emeraldgrouppublishing.com/licensing/reprints.htm Or contact us for further details: permissions@emeraldinsight.com 